\title{
Pathogenesis of Autoimmune Male Infertility: Juxtacrine, Paracrine and Endocrine Deregulation
}

\author{
Valeriy A. Chereshnev ${ }^{1}$, Svetlana V. Pichugova ${ }^{1,2}$, Yakov B. Beikin ${ }^{2}$, Margarita V. Chereshneva ${ }^{1}$, Angelina I. Iu- \\ khta ${ }^{3, *}$, Yuri I. Stroev ${ }^{3}$ and Leonid P. Churilov ${ }^{3,4}$ \\ 1 Institute of Immunology and Physiology, Ural Branch of the Russian Academy of Sciences, Yekaterinburg, \\ Russia; iip@iip.uran.ru \\ 2 State Autonomous Healthcare Institution of the Sverdlovsk Region "Clinical and Diagnostic Center" (GAUZ \\ SO " CDC" Clinical Diagnostic Center), Yekaterinburg, Russia; inbox@kdc-lab.ru \\ 3 Saint Petersburg State University, Russia; 1.churilov@spbu.ru \\ 4 Saint Petersburg Research Institute of Phthisiopulmonology; info@spbniif.ru \\ * Correspondence: ang22748@gmail.com
}

\begin{abstract}
According to global data, there is a male reproductive potential decrease. Pathogenesis of male infertility often is associated with autoimmunity towards sperm antigens essential for fertilization. Antisperm autoantibodies (ASAs) have immobilizing and cytotoxic properties, impairing spermatogenesis, causing sperm agglutination, altering spermatozoa motility and acrosomal reaction, thus preventing ovum fertilization. Infertility diagnosis requires mandatory check for the ASAs. The concept of blood-testis barrier currently is re-formulated with emphasis of informational paracrine and juxtacrine effects, rather than simple anatomical separation. Aetiology of male infertility includes both autoimmune and non-autoimmune diseases, but equally develops through autoimmune links of pathogenesis. Varicocele commonly leads to infertility due to testicular ischemic damage, venous stasis, local hyperthermia, and hypoandrogenism. However, varicocelectomy can alter blood-testis barrier facilitating ASAs production as well. There are contradictory data on the role of ASAs in pathogenesis of varicocele-related infertility. Infection and inflammation both promote ASAs production due to "danger concept" mechanisms and because of antigen mimicry. Systemic pro-autoimmune influences like hyperprolactinemia, hypoandrogenism and hypothyroidism also facilitate ASAs production. Diagnostic value of various ASAs was not yet clearly attributed, and their cut-levels not agreed neither in sera nor in ejaculate. The assessment of the autoimmunity role in pathogenesis of male infertility is ambiguous, so the purpose of this review is to show the effects of ASAs on the pathogenesis of male infertility..
\end{abstract}

Keywords: male infertility; varicocele; varicocelectomy; spermatozoa; sperm antigens; antisperm autoantibodies; ejaculate; orchitis; autoimmune thyroiditis

\section{Introduction}

In recent years, infertility has become a global health problem [1]. Increasing number of men suffer from impaired fertility, while the incidence of the male factor of infertility reaches $30-50 \%$ in infertile couples [2-7]. The reproductive potential of the world male population is declining steadily and there is no tendency to improvement [7-11]. The etiology of male infertility is still a matter of debate among various specialists, but influence of both exogenous and endogenous factors is noticed, combining negative effects on spermatogenesis and various stages of the fertilization [12, 13]. Hence, male infertility is a multifactorial syndrome that includes a wide range of disorders, affecting not only the reproductive system, but also the immunoneuroendocrine apparatus [10, 14, 15]. The most common causes of male infertility are genitourinary malformations, genetic disorders (particularly, cystic fibrosis and chromosome aberrations), congenital diseases of the male reproductive system (cryptorchidism, monorchism, phimosis, and hypospadias), varicocele, neuroendocrine disorders and chronic stress, traumas and inflam- 
matory diseases of the reproductive tract, both with infectious and non-infectious etiology, lifestyle factors (alcohol, tobacco smoking, drug addiction), and testicular tumors [5, 11, 14-25]. Immunopathological factors are leading in pathogenesis of male infertility, essential for its cases regardless of different etiology.

\section{Sperm Antigens and Antisperm Antibodies (ASAs): Past and Present}

In 1901-1903 Russian pathophysiologist Efim S. London obtained the "spermolysins" - cytotoxic antibodies against spermatozoa and predicted their pathogenic role in male infertility and potential use as a contraceptive in andrology [26, 27]. At the same time, another Russian scholar Sergei I. Metalnikov obtained the very first experimental model of male infertility using "spermolysins" in animals [28]. Nowadays, 120 years later, ASAs production is considered as one of the main mechanisms of male infertility [14, 29-32]. The presence of ASAs in blood and semen of infertile men was first reported by Philip Rümke in Netherlands and Leo Wilson in USA back in 1954, and since then researchers have focused on them [7, 33, 34]. But active clinical pathophysiological studies of autoimmunity as a mechanistic factor contributing to the formation of male infertility began after 1965 [35, 36]. In recent decades, immunological form of infertility attracted more attention due to establishment of the role of ASAs as a direct cause of infertility, since a higher levels and incidence of ASAs were diagnosed in infertile men compared to healthy ones [13, 37-41]. Nowadays there is an opinion that pathologically enhanced autoreactive immune response to the antigens of reproductive system can lead to infertility, and ASAs are the immunological markers valid for assessment of impaired male fertility $[29,39-41]$. ASAs is determined in $10 \%$ of infertile men, and the frequency of the immunological form of infertility is $4.5-15 \%$ in various populations $[2,7,13,41,45-48]$.

It is known that autoimmunity to sperm can result from inflammation of testicles (orchitis), both of infectious or non-infectious origin [13-15, 20, 21, 23, 32, 44, 49-52]. Commonly non-infectious orchitis occurs in traumas (including biopsy, invasive procedures and surgical intervention such as vasectomy - in $20-30 \%$ cases). In general, the development of an immunological infertility is associated with any damage to the testicle. According "danger hypothesis" by P. Matzinger, such a situation of non-specific inflammation via pro-inflammatory autacoids increases the expression of co-stimulatory molecules on immune cells, thus prolonging the existence of immunosynapses between antigen-presenting cells and autoreactive lymphoid clones. As a result, autoimmunity increases and may reach pathological intensity [53]. Also, local damage for a long time was interpreted as a factor destroying 'immune privilege' of the testis, simplistically attributed to the existence of the anatomical blood-testis barrier. In fact, this point of view is getting obsolete because the "barrier" currently is regarded not as an anatomical obstacle for antibodies, but informational barrier established by local paracrine/juxtacrine action of anti-inflammatory cytokines produced in testis and down-regulation of autoimmunity by androgens [54]. Anyway, local inflammation breaks relative immunological tolerance, which event may have serious consequences for the reproductive system $[2,7,10,11,22$, $25,41,46,55-60]$.

\section{Immune Privilege of Testes: Informational, Not Only Anatomical Barrier}

Testicular immunological tolerance is formed in the perinatal period due to blood-testis and blood-epididymis barriers and immunosuppressive activity of the paracrine and endocrine products of testicle cells [24, 54, 61-63]. The building of the blood-testis barrier begins with the formation of tight junctions between Sertoli cells, while the first germ cells enter the meiotic phase [2, 15, 64]. The brief scheme of blood-testis barrier by Cheng C. Y. and Mruk D.D. [65] has shown on Figure 1. 


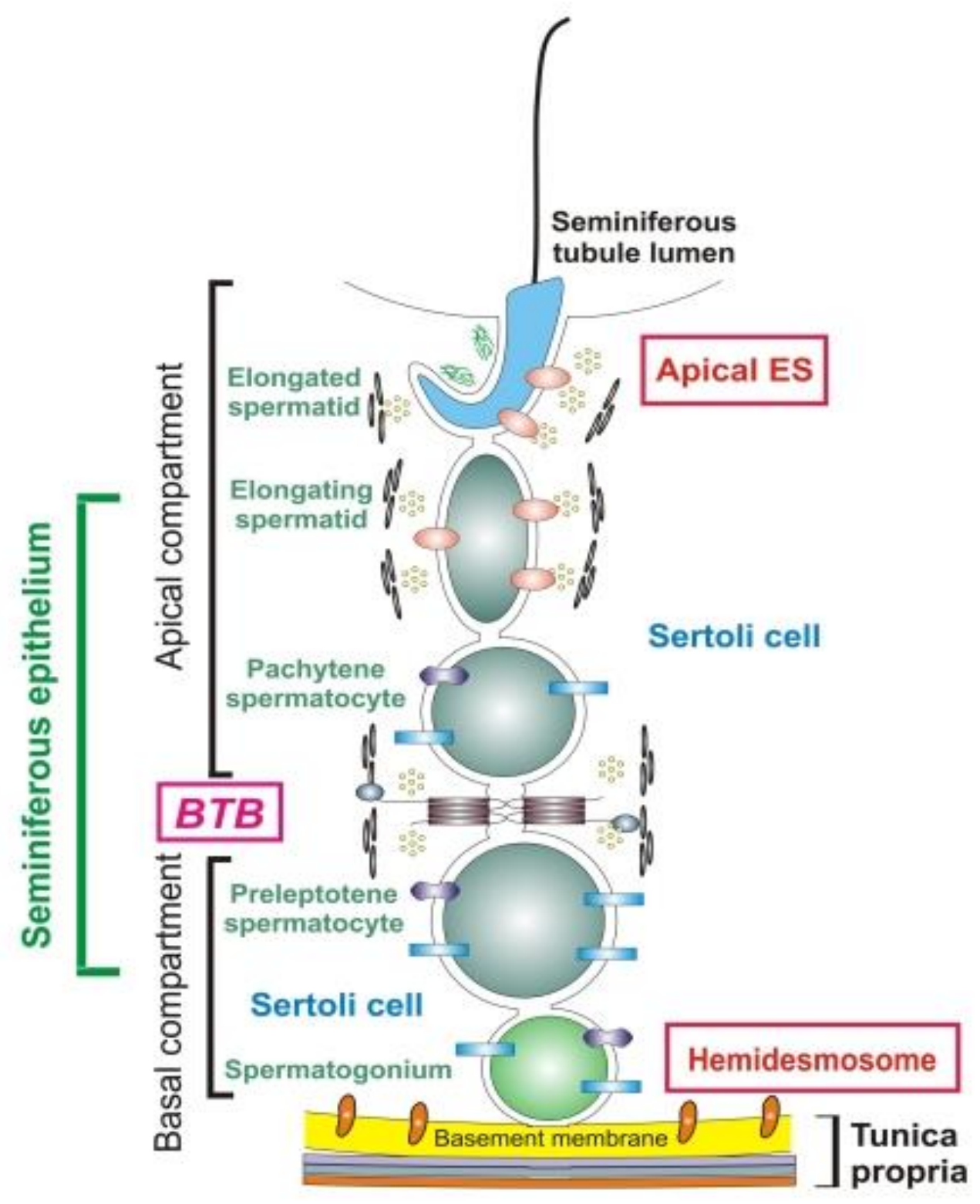

Figure 1. The structure of blood-testicular barrier (BTB) (fragment from Cheng C.Y., Mruk D.D., 2012) The BTB is formed by tight junctions, basal ectoplasmic specialization, desmosome and gap junctions, and the ultrastructural features of the BTB as typified by the actin filament bundles sandwiched between the cisternae of endoplasmic reticulum and the plasma membranes of two opposing Sertoli cells [65].

Sertoli cells form the basis of the blood-testis barrier; they are located along the length of the seminiferous tubule and relatively isolate the site of spermatogenesis $[24,30]$. The vascular component of the blood-testis barrier consists of capillary endothelial cells with low permeability, which hampers the passage of lymphocytes and high molecular weight proteins [30]. During puberty, when the germ cells complete their first spermatogenic cycle, differentiating into mature spermatozoa, the testicular immune privilege is put under challenge [24,59]. A lot of new surface molecules are expressed, which, together with the autoantigens of developing spermatozoa, are presented to the immune system. Thus, lymphoid clones maybe not tolerated to them centrally, and their tolerance in these cases critically depends on peripheral local mechanisms [15, 66, 67]. In addition, in tubuli recti and rete testis this shield is absent or frails, hence purely anatomical interpretation of blood-testis barrier is insufficient and outdated [15, 24, 66]. Young spermatocytes and spermatogonia are located outside the blood-testis barrier and their 
antigens can be accessed by all elements of immune system [24]. During spermatogenesis, specific antigens of meiosis are expressed on cells, and in plus up to 20 additional antigens appear on the membranes of spermatozoa during their passage and maturation in the epididymis [24, 30].

The most essential content of the term "blood-testis barrier" is rather informational, but not anatomical protection. Sperm autoantigens are available and recognized by immune system, but usually they do not activate the pathogenic immune response due to the presence of a peritubular immunoregulatory system, which is the most essential "non-anatomic" or informational part of the blood-testis barrier [14, 30, 66].

Several bioregulation mechanisms are involved for establishing peripheral tolerance in testicles: anti-inflammatory polarization and decreased reactivity of resident macrophages, inhibited proinflammatory and enhanced tolerogenic cytokines induction by testicular androgens (especially during and after puberty), anti-inflammatory cytokines production by local T-regulatory cells and somatic cells, antigen-specific immune suppression by tolerogenic local dendritic cells, and dormant local mastocytes [66, 67].

The blood-testis barrier carries out immunoregulatory juxtacrine and paracrine control by stimulating the release of specific immunoprotective substances from Sertoli cells and Leydig cells, which suppress blast transformation of lymphocytes and prevent lysis of spermatozoa [30]. Some studies have shown the immunosuppressive inluence of Sertoli cells in vitro on the activated T-lymphocytes [24]. The phagocytic activity of Sertoli cells consists in the degradation of spermatozoa and their antigenic components, normally without antigen presenting. Sertoli cells interact with syngenic T-lymphocytes in order to establish testicular immune privilege, and this interaction is HLA-restricted. They impede penetration and survival of T-effectors and Th17, at the same time facilitating T-regulators [30, 66, 68]. Normally T-regulators prevail among local lymphocytes over T-effectors and block excessive autoimmunity in spite of existing autorecognition $[65,66]$. But testicles for sure are normally available for lymphocytes of all subpopulations, moreover, CD8+ T-effectors are essential for the physiologic regulation of testicular germ cell population balance via their apoptogenic signals, hence if old concept of absolute immune isolation of gonads could be true, normal development and renewal of germ cells would not be possible [69].

Thus, the immune mechanisms of the testicles are physiologically and immunologically prepared both by local (para- and juxtacrine) and by systemic androgen-mediated endocrine regulation to protect sperm autoantigens from the destructive autoreactive response, and the presence of a blood-testis barrier makes the testicles an immunologically privileged site $[59,70]$.

\section{Role of Epididymis}

ASAs production may depend on events happening in the region of the epididymis, which is protected by the hemato-epididymal barrier, first described by D.S. Friend and N.B. Gilula in 1972 [70, 71]. The epididymis is a highly specialized organ involved in the maturation, transport, protection and storage of sperm before ejaculation. The blood-epididymal barrier anatomically consists of tight junctions between epididymal cells, and transporters located along their surface, which regulate the bidirectional movement of molecules, promoting sperm maturation and establish the relative separation of sperm antigens from the cells of the immune system. Although the hemato-epididymal barrier is architecturally more complicated than the blood-testis one, it is anatomically even less effective, which makes the epididymis generally more susceptible to immune influences in comparison with testicles [70]. Maturation of spermatozoa occurs, when they are passing through the epididymis, accompanied by surface fixation of many proteins synthesized by the epididymal cells. Probably, all above mentioned makes it possible to mark the epididymis as a key site of ASAs generation eliciting $[46,70]$. 
The formation of ASAs in men may be associated with impaired immunoregulatory mechanisms or the development of pathological processes increasing the degree and duration or auto-presentation in the testicles and/or epididymis. Lack of local and systemic tolerogenic influences and/or enhancement of local/systemic adjuvant effects may shift the balance towards abnormal excessive anti-sperm autoimmunity.

\section{Targets of ASAs: Assorted Mosaic}

The immunological form of infertility will be diagnosed if ASAs with immobilizing or agglutinating properties are found in the patient's blood or fluids of the reproductive tract $[29,72]$. The target sperm autoantigens are specific proteins related to fertilization and fertility, each of them has unique structure and is synthesized by different cells of the reproductive system [7, 32, 72-74]. The most studied among them currently are the proteins YWK-II (protein of the equatorial sector of the sperm head), BE-20 (protein of the epididymis), rSMP-B (sperm tail antigen), BS-17 (calpastatin), ACTL7a (an actin-like protein), BS-63 (nulloprotein of testis), HED-2 (a component of Sertoli cells), EP-20 (epididymal glycoprotein of 20kDa molecular mass), NASP (autoantigenic nuclear protein), FA-1 (specific fertilization antigen), YLP12 (dodecamer peptide specific for acrosomal region of human sperm cells), HSP 70 and HSP 90 (heat shock proteins) and many others $[24,29,72-75]$.

Interestingly, it appeared that in many cases ASAs are addressed not to genuine autoantigens of spermatozoa, but to immunodominant autoantigens of prostasomes (extracellular vesicles of 40-500 $\mathrm{nm}$ in diameter, which normally are secreted by the prostate gland epithelial cells into seminal fluid and use to fix on spermatozoa). Among them most frequent targets of ASAs are clusterin and prolactin-inducible protein (PIP), with 10 others prostasome proteins revealed just sporadically [76]. Presence of anti-PIP among ASAs is to our opinion especially remarkable (see below in section 9 data on hyperprolactinemia as a factor increasing the risk of autoimmunity).

Sperm antigens are localized on the head of spermatozoa, in the acrosome, as well as on the flagellum and regulate sperm motility, provide capacitation and initiation of acrosomal response [72, 77].

ASAs (Ig A, M, and G) can be found in blood serum and ejaculate (only IgA and IgG, but not the IgM, due to its size) [2, 11, 39, 41, 42, 46, 74-78]. In addition, ASAs can be addressed to surface or intracellular sperm antigens [24]. IgA and IgG can passively diffuse into the reproductive tract, but IgA can be also actively secreted by the germ cells. Epithelial cells produce a secretory component that acts as a regulatory transport protein for IgA. Antigenic epitopes in infertile men bind more avidly to local IgA than to IgG, and IgG is less reactive against sperm antigens [30]. The detectable amounts of ASAs IgA may be absent in blood serum, however, their local presence in the genital tract can lead to dysfunction of spermatozoa [24]. It is known that excessive binding of ASAs by spermatozoa may diminish their levels detected in seminal plasma [72]. The degree of fertility impairment depends on the class of autoantibodies, their amount, specificity and density of their coverage on the sperm cell surface $[2,7]$.

Regardless of the type of ASAs, they can be fixed on different parts of the sperm cells depending on their specificity. Usually, autoantibodies that react with sperm surface antigens are agglutinins or immobilisins and cause different types of spermatozoa agglutination (head + head, head + flagellum, flagellum + flagellum) [30]. Presumably, those ASAs that interact with the antigens of the membranes of vitally important antigens of the sperm cell will be of clinical value [24]. Thus, the attachment of autoantibodies to the flagellum of the spermatozoa will lead to impairment of cell mobility, while fixation on the head will lead to impaired penetration of the spermatozoa into the cervical mucus $[24,30]$. Autoantibodies bound to the acrosomal region can interfere with the acrosomal reaction, leading to the occlusion of receptors necessary for attachment to the transparent membrane of the ovum, thus preventing fertilization [30,32]. ASAs fixation on sperm can not only lead to agglutination and immobilization [14, 29], but also has a cytotoxic effect 
mediated via complement and/or macrophages or other K-cells [2, 41, 79]. Binding of IgG and complement proteins initiates C-3-mediated interaction of spermatozoa with polymorphonuclear cells and inactivation of spermatozoa through the deposition of the membrane attack complex (MC5b-9) of the complement. Cytotoxic antibodies, especially in seminal plasma, can cause a premature acrosomal reaction, since a large number of antigens are concentrated on the acrosome as a membrane structure [15, 30, 64]. The combined effects of various ASAs on different components of spermatozoa can also lead to immunological infertility [24].

It has been noticed that the quality of sperm deteriorates significantly in the presence of ASAs [80]. The effect of ASAs on reproductive function can be realized in various ways: impaired spermatogenesis, sperm agglutination, decreased motility, impaired penetration of spermatozoa into cervical mucus, impaired acrosomal reaction, obstruction of ovum fertilization, impaired embryo implantation and deranged early development of zygote $[2,29,32,39,55,70,78,81-85]$. Due to relatively small number of cases involved in studies, no statistically significant correlation of infertility was established so far with antibody isotypes, titers of ASAs, age of men, or sperm count [24, 30].

ASAs-mediated infertility should be suspected if sperm agglutination and motility impairment are diagnosed by semen analysis in the absence of leukocytospermia and infection $[24,30,86]$.

It's also interesting that some articles show that vitamin $\mathrm{D}$ binding protein has a molecular similarity to ASAs, and both low ( $<50 \mathrm{nmol} / \mathrm{L})$ and high $(>125 \mathrm{nmol} / \mathrm{L})$ concentration of vitamin $\mathrm{D}$ are associated with decreased number and quality of spermatozoa in semen [87].

In spite of all data cited above, the link between the presence of ASAs in men and infertility continues to be disputed, and it is unclear whether ASAs adversely affect the outcome of in vitro fertilization (IVF) or results of intracytoplasmic sperm injection (ICSI) [88].

Studies on the likelihood of fertilization after IVF have yielded conflicting results, with some data showing negative effects of ASAs, while others have shown no negative effects at all. Perhaps, that is due to differences between ASAs of various molecular specificity, which is not registered in most of assays.

Studies on ASAs and post-ICSI pregnancy rates have generally shown that ASAs do not affect post-ICSI pregnancy rates [59, 88-91].

It should be noted that ASAs in the immunological form of infertility are formed not only in men, but also in women.

Several researchers showed that among women with unexplained infertility, ASAs activity has been detected in cervical mucus in more than $10 \%$ of cases. Moreover, ASAs from female serum could inhibit the fertilization of viable human eggs by spermatozoa, and the fertilization rate was only $15 \%$ for female patients who had significant blood titers of IgG and IgA ASAs. Later experimental results in vitro confirmed that high-titer ASAs IgG in female serum could effectively inhibit fertilization [92]. R. Bahraminejad et al. [93] showed that prostitutes have significantly higher titers and a wider target spectrum of ASAs than women, having one sexual partner, and the intensity of antisperm autoimmunity in this group correlates with the percentage and timing of infertility.

As regards to natural conception, ASAs may be a possible cause to decrease reproductive potential in women with secondary infertility, particularly, increased miscarriage rates in women with ASA were demonstrated by some authors [94-96]. However, there is evidence that in women with polycystic ovary syndrome or endometriosis, ASAs do not play a significant role in the occurrence of infertility, and also do not cause miscarriage in the first trimester [97-100].

\section{ASAs and Varicocele}

As it was mentioned above, any non-specific damage increases the intensity of auto presentation in damaged tissue, especially if it is accompanied by inflammation [53]. 
Varicocele is characterized by varicose veins of the spermatic cord; its incidence among males is $15-40 \%$, which makes it the most common andrological entity [81, 83, 101-103]. Being an aggressive form of orchopathy, varicocele causes highly increased risk of infertility [1, 101, 103-107].

Varicocele's association with infertility is based on the number of observations by different authors more often diagnosing it among infertile men, than in general population. Also, it is accompanied by abnormalities in the spermogram parameters [104]. The peak of varicocele reveals falls on puberty, it occurs in $15-19 \%$ of adolescents of this age group and can limit in future reproductive potential of this cohort [19, 108].

The pathogenesis of varicocele is multifactorial [84, 108]. It causes congestion of local blood circulation. Hypoxic damage of the testicular parenchyma, relative scrotal hyperthermia, venous hypertension and passive hyperemia reflux of metabolites and bioregulators (catecholamines) from the kidneys and adrenal glands, and hypoandrogenism are considered as the main mechanisms resulting in damage to the blood-testis barrier [7, 15, $58,81-83,103]$. There occurs disruption of the transport of water, lactate and other substances in Sertoli cells [64, 83, 109, 110]. All these mechanistic links in pathogenesis of varicocele lead to an increase of oxidative stress, decrease of tolerogenic influences, and increase in ASAs production [59, 110]. Also, a decrease in the expression of E-cadherin and alpha-catenin at the junctions of Sertoli cells was found in varicocele, which can increase permeability of the blood-testis barrier $[83,111]$. As already noted, ASAs are often found in infertile men with varicocele $[7,41,59,81]$. Immunological infertility was registered in 15-28\% of men with varicocele [78, 80, 108, 112]. In addition, B.R. Gilbert et al. as early as in 1989 established that ASAs are present in greater quantities in infertile men with varicocele than in infertile men without it, and this was later confirmed in by A.M. Al-Daghistani et al., and a number of other researchers [30, 58, 83, 108, 110, 112-116].

The presence of ASAs in varicocele is accompanied by a deterioration in sperm parameters, in particular, there is a decrease in progressive sperm motility (asthenozoospermia is diagnosed most often), as well as a decrease in the concentration and total number of spermatozoa, with violation of the acrosome reaction $[39,40,58,81,82,103$, 110-116].

But, on the contrary, Kanevskaya T.A. et al. showed that ASAs did not increase notably in infertile men with varicocele compared with infertile men without it. According to their study, ASAs did not correlate significantly with male infertility in varicocele [117]. Several other groups also demonstrated that varicocele did not affect the concentration of ASAs, and ASAs, in turn, did not affect the parameters of sperm in varicocele. Moreover, concentrations of ASAs in fertile or infertile varicocele patients were close [78, $83,112,114,118]$. In a Finnish cohort of 508 infertile men the levels of ASAs among those having fresh or anamnestic varicocele were even lower than in infertile men without varicocele [119]. Hence, there is an assumption that autoimmune mechanisms are not the single or even not the main cause of infertility in varicocele. Presumably, ASAs role is permissive and accompanied by additional damaging factors, for example, trauma, infection and resulting inflammation $[46,78,82,83,112,118]$.

\section{Sperm Autoimmunity and Varicocelectomy: Conflicting Data}

Varicocele is traditionally considered a potentially curable cause of male infertility, and varicocelectomy still serves as the gold standard of treatment; however, surgical intervention often fails to restore fertility, improve semen analysis, so the outcome of the operation remains poorly predictable [24, 51, 76]. Earlier ASAs were not considered as a factor that negatively affects the result of surgical treatment, but nowadays many researchers reported ASAs level increase after surgical intervention [42, 43, 50, 78, 80, 86, $117,120-122]$.

The results of varicocelectomy may be equivocal. Several groups found that in those cases when the patients operated upon did not show an improvement in spermogram parameters (still displaying impaired sperm motility), there were higher levels of ASAs 
registered. In the long-term postoperative period, an improvement in spermogram parameters was noticed mainly in patients initially negative for ASAs [81, 82, 112-114]. In a number of studies after the surgery, an increase in the level of ASAs was recorded, but it did not cause any negative effect on sperm parameters [78, 84, 123], Nevertheless, one study of 2016 noted after varicocelectomy a decrease in ASAs compared to their initial levels, and an improvement in spermogram, primarily, in sperm motility [55]. The majority of works did not register any significant differences between the concentration of ASAs before and after varicocelectomy, including data of the long-term postoperative period $[42,83,114,116]$.

In general, in those patients without ASAs varicocelectomy most often leads to an improvement in sperm parameters. If ASAs-positive ones result of surgical treatment looks less successful. Most often varicocelectomy increases or does not alter the titer of ASAs, but there are few articles describing its post-operative decrease.

\section{Anti-Sperm Autoimmunity and Infection: Essential Trigger}

As already noted by some researchers, infection of the reproductive tract is one of the common causes of male infertility, potentially curable, but, nevertheless, leading to a decrease in sperm quality due to various mechanisms. One of them is an oxidative stress causing fragmentation of sperm DNA and initiating apoptosis [48, 60, 124-126].

Also, any local infection provoking inflammation shifts the balance of pro- and contra-autoimmune bioregulators towards excessive autoimmunity, increasing the presence and influences of T-effectors and diminishing the number and activities of T-regulators and/or changing the trend of macrophages' polarization $[7,14,53,54,59,66$, 67]. Many molecules expressed during infectious process are in fact endogenous adjuvants enhancing auto presentation and autoimmunity. Particularly men who had leucocytospermia associated with bacteriospermia, demonstrated elevated expression of Toll-like receptors 2 and 4 and showed significant increase in oxidative stress indices, immune response against spermatozoa and spermal dysfunction [29].

In general, infectious processes can disrupt local immune regulation, can damage spermatozoa directly or through an inflammatory reaction, leading to the formation of ASAs [122]. It was found that in more than $40 \%$ of cases, ASAs to sperm surface antigens were found in infected patients, which is significantly higher rate than among uninfected infertile and fertile men [126].

The human body is a habitat for a huge number of different types of bacteria, viruses, fungi, and parasites, which underwent a long co-evolution with us. Hence, the phenomenon of molecular mimicry, used by microorganisms to suppress the host's immune response, gives them the ability to initiate autoimmunity by mimicking host proteins, including sperm antigens, therefore, molecular mimicry may be a crucial mechanism causing autoimmune infertility of infectious aetiology [126].

The idea of molecular mimicry was coined in biology by a Russian zoologist Konstantin S. Merezhkovsky in the very beginning of 20th century [128], and in last decades enrolled a lot of proponents among immunologists [129].

Indeed, ASAs are found in people who do not have any obvious anamnestic reason for their production [7]. Either that fact should be interpreted as a witness for doctrine of physiological autoimmunity and autoimmune regulation of morpho-functional processes in testes [130], or, alternatively, the reason is hidden immune response against some microorganisms sharing epitopes with the spermatozoa [129]. For example, a specific immune response to Chlamydia trachomatis, the causative agent of the most common sexually transmitted infection, can lead to inflammation and impaired fertility by DNA fragmentation and also by activating immune responses to an epitope of a heat shock protein, shared by Chlamydia and human sperm cells, which is accompanied by high levels of ASAs [21, 29, 125, 127]. The epitopes shared with sperm cell antigens have been found in many microbial antigens from: Escherichia coli, Bacillus sp., Staphylococcus aureus, Streptococcus pyogenes, Streptococcus agalactiae and many viruses [7, 29, 126, 
127, 131]. Helicobacter pylori is also considered as a possible initiator of autoimmunity to spermatozoa, since spermatozoa are the only human cells possessing with flagella, the possibility of their homology with bacterial flagella cannot be ignored [127]. Thus, not only pathogens of sexually transmitted infections, or other pathogenic microorganisms, but also germs of opportunistic flora can initiate autoimmune reactions against spermatozoa. However, D. Kanduc emphasized recently [129] that virtually all microbes and viruses have some epitopes shared with some human peptides. It does not necessarily mean that such a germ will inevitably provoke an autoimmune process in all humans. The point is that individuals with different HLA haplotypes may process the same proteins absolutely differently, slicing them on various peptides and responding with different strength in the context of individual set of major histocompatibility complex antigens. For example, mumps is well-known reason of viral orchitis. But nevertheless, the levels of ASAs in infertile men experienced mumps in anamnesis appeared to be lower than in those infertile men who never suffered from this infection [119].

Anyway, if aetiology of male infertility is anamnestically related to infection, it does not mean that autoimmune mechanisms are not involved in its pathogenesis. Both "danger hypothesis", postulating the adjuvant effect of infectious inflammation on auto presentation and autoimmunity [53], and molecular mimicry concept allowing anti-self B- and T-effectors start their job after help from anti-alien T-helpers [127, 129]-give a substantial theoretical basis for such scenario.

The current pandemic of new coronavirus infection COVID-19 also may alter male fertility, addressing to autoimmune mechanisms. It has been demonstrated that Sertoli cells, Leydig cells and spermatogonia all express ACE2 receptor offering a gate for SARS-CoV-2 penetration [132]. Moreover, the cases of orchitis and orchiepididymitis were registered in males after SARS-CoV infection in the past, and after COVID-19 [133-135].

\section{Systemic and Multiorgan Autoimmune Diseases and ASAs}

Systemic and multiorgan autoimmunopathias can adversely affect male fertility. In particular, autoimmune thyroiditis, especially in advanced cases, leading to hypothyroidism, has a profound negative effect on the male reproductive system. The reasons are not only share of some thyroid and sperm antigens, like human meichroacidin [136], but most probably, the systemic action of endocrine disorders in Hashimoto's thyroiditis. Thyroid hormones via genetic, epigenetic and non-genomic mechanisms, in particular, by paracrine action on Sertoli cells, Leydig cells or spermatozoa are involved in maintaining sperm quality, with $\alpha$ and $\beta$ receptors for thyroid hormones expressed in the human testicles. [137] It has been shown that thyroid hormones act directly on calcium channels, providing an increase in calcium influx and cAMP synthesis, activating protein kinase A, which causes movements of spermatozoa, leading to their hyperactivation [138]. Moreover, thyroliberin, produced in Hashimoto's thyroiditis patients as a compensatory response to coming hypothyroidism, has also considerable prolactogenic activity. Because of that, advanced cases of Hashimoto's thyroiditis almost always cause hyperprolactinemia [139]. Hyperprolactinemia suppresses androgen production (which decreases androgen influences essential for establishment of testis immune privilege) [140]. In plus prolactin acts as potent autoimmunity stimulant both on endocrine and paracrine levels [141]. As it was mentioned in section 5 above, PIP of prostasomes attached to spermatozoa is one of the proven targets of ASAs [76]. Thus, the vicious circle in Hashimoto's thyroiditis is formed: the more destructive is autoimmune process, the deeper hypothyroidism, greater degree of hyperprolactinemia and again stronger autoimmunity develops [139].

This complex of endocrine disorders makes Hashimoto's thyroiditis an important risk factor for male infertility. In our studies it was found that the level of anti-thyroid peroxidase autoantibodies (markers of this disease) correlated positively with pathozoospermia [142]. Long-term non-compensated hypothyroidism leads to pituitary dys- 
function, hyperprolactinemia and hypogonadism [143]. Ultimately, hypothyroidism in autoimmune thyroiditis negatively affects the spermatozoa morphology, sperm motility and deteriorates the parameters of the spermiogram. Levothyroxine therapy reverses these abnormalities [130, 144, 145]. Thyroid hormones in treatment of Hashimoto's thyroiditis act not only as a replacement therapy, but also as immunomodulating agents, because they suppress hyperprolactinemia with its pro-autoimmune effects and even facilitate the apoptosis of lymphoid clones [146, 147]. Autoimmune thyroiditis often combines with other autoimmune diseases, sometimes, with autoimmune orchitis. For example, amiodarone (anti-arrhythmic medicine with huge content of iodine) induces both thyroid and testicular autoimmunity [148]. In Hashimoto's thyroiditis increased level of autoantibodies to steroid-producing cells may be observed, with decreased serum testosterone, which causes altered spermatogenesis, resulting in low concentration of spermatozoa, a decreased number of progressive motile spermatozoa and morphologically abnormal spermatozoa in semen [149]. If autoimmune orchitis was caused by with systemic vasculitis, like in systemic lupus erythematosus (SLE), the patients also may be ASAs-positive. ASAs have been reported in almost half of male SLE patients. Testicular inflammation may induce $\mathrm{T}$-cell response with pro-inflammatory cytokine production and resulting blood-testis barrier alteration, ASAs production and apoptosis of spermatozoa [14].

The Bulgarian researchers reported multiple targeted autoimmunity including ASAs and various rheumatological marker autoantibodies in 55\% of infertile couples for both partners [150]. There are also studies showing increased incidence of ASAs and secondary autoimmune orchitis in males with various systemic autoimmune diseases, such as: polyarteritis nodosa, Behçet's disease, rheumatoid arthritis and Henoch-Schönlein purpura. The overall frequencies of acute orchitis and ASAs in rheumatic diseases are $2-31 \%$ and $0-50 \%$, respectively is significantly higher than in healthy controls [151, 152].

\section{Methods of ASAs Detection}

ASAs in men can be determined in blood serum, seminal plasma, or on the surface of spermatozoa using various tests. An ideal test for the diagnosis of autoimmunity to spermatozoa should detect the presence of ASAs, their localization and isotype, with high sensitivity and specificity. The existing tests are compared and described in detail elsewhere [24], here a brief synopsis follows.

There are several tests for detecting ASAs, described in detail by Hulusi B. et al. [24].

The presence of ASAs in blood serum or semen can be revealed by agglutination test using washed motile sperm from a healthy donor, added to diluted patient samples. In addition, known positive and negative controls are required. The test results are evaluated using light microscopy and the test is considered positive in cases where there is a clear agglutination of sperm/ A titer of $1 / 32$ is considered of clinical value. This test allows to determine the type of agglutination but does not provide quantitative data and requires a healthy sperm donor.

Another available test for detecting ASAs is the sperm immobilization assay, a complement-dependent analysis of sperm motility. ASAs interact with sperm antigens activating the complement system, which leads to a violation of the permeability and integrity of the sperm membrane, followed by loss of mobility and cell death. The results are also recorded using light microscopy. The disadvantages of the method include the lack of quantitative data; besides only immobilizing antibodies are determined. Moreover, IgA is not detected at all since they do not fix complement.

The MAR (mixed agglutination response test) is used to detect ASAs with erythrocytes, on which IgG to sperm antigens are conjugated. The method is semi-quantitative, evaluated by light microscopy. The test is easy to perform, but it has several weak points. The method cannot be used in patients with oligozoospermia and asthenozoospermia; motile spermatozoa are required, hence immobilizing antibodies are not evaluated; an 
excess of erythrocytes obstacles correct assessment of the sites of binding with spermatozoa; the presence of mucus, microorganisms, and non-immunoglobulin proteins interferes and can cause false positive results [24].

A modification of the MAR test is the Sperm MAR test, in which latex beads conjugated to IgG or IgA are used instead of erythrocytes. When a highly specific IgG is fixed on the beads when spermatozoa are added, the beads are attached strictly to the area where the antigen is localized. The Sperm MAR test for IgA detects only secretory IgA in semen. Nevertheless, among all the ASAs tests, the MAR test showed the highest performance. It is considered positive when more than $40 \%$ of spermatozoa bind to latex particles when tested for IgG [24].

For IBT (indirect beads tests), polyacrylamide beads coated with a specific anti-immunoglobulin are used. The direct IBT test is used to determine the ASAs in semen, and the indirect test can be used in seminal plasma with a small number of motile sperm. The binding of the beads to sperm is assessed using light microscopy. The principles of IBT are shown in Figure 2 [152]. The test is considered significant if 50\% or more of motile spermatozoa are covered with beads. Compared to the tests described above, the IBT test has a number of advantages, such as the ability to determine the isotype of ASAs, their localization, also it has high sensitivity and specificity [24, 153, 154].

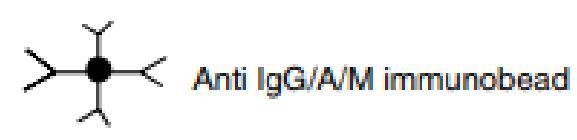

Bead binding over tail

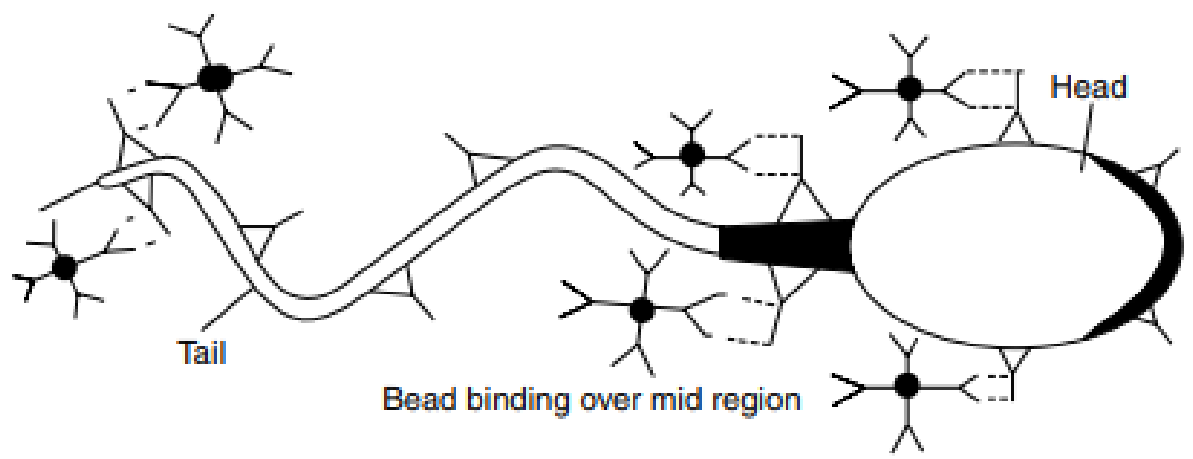

Bead binding over head

Figure 2. The scheme of immunobead test (IBT) (fragment from Sikka, S.C., Hellstrom, W.J.G., 2019). The immunobeads are microscopic polyacrylamide spheres which carry covalently bound rabbit antibodies directed against human immunoglobulins. Sperm and beads are mixed, and the suspension is observed by microscopy for agglutination of sperm and beads. By using beads coated with Ig-class-specific antibodies, one can identify the different antibody classes involved (IgG, $\operatorname{IgA}$, $\operatorname{IgM)}[153]$.

The WHO recommended both MAR and IBT tests as screening methods for ASAs reveal [7, 11, 35, 120-122, 155]. The MAR test is considered sufficient because IgA almost never occurs without IgG, and, as it was already mentioned, there is a variant of the Sperm MAR test that can detect IgA associated with sperm [24].

In addition, a common and effective test for the diagnosis of immunological infertility is the enzyme-linked immunosorbent assay (ELISA), which allows the determination of IgA and IgG in blood serum and on the surface of spermatozoa, and many researchers prefer to use this method for diagnosis, despite the WHO recommendations $[10,44]$. The essence of the method lies in the fact that ASAs to specific immunoglobulins are covalently bound to enzymes and antibody-enzyme-Ig complexes are detected by adding an enzyme substrate, which leads to a color change. Thus, the ASAs level can be quantified. A significant disadvantage of the method is the use of fixed sperm, since fix- 
ation can lead to a violation of the integrity of the sperm membrane and intracellular antigens will participate in the reaction, altering the results. Also, this technique does not allow to check the isotype of antibodies, their localization, and has relatively lower sensitivity and specificity [24].

Another common method of ASAs reveal is flow cytometry. The antibody-coated spermatozoa are incubated with fluorescent antiglobulin, followed by detection with a magnet or laser in a continuous flow. The undoubted advantages of the method include: the ability to determine the isotype of immunoglobulins, and quantitative assessment of spermatozoa positive for antibodies. But there is a high probability of detachment of the antigen-antibody complex from the sperm surface during diagnostic manipulations, leading to a distortion of the result [24].

Few other methods of ASAs evaluation are in use, almost exclusively in research practice, including radioimmunoassay (radioactively labeled antiglobulin assay), immunofluorescence method, affinity chromatography, and immunoblotting, but they are not used in routine [24,59].

Recently the computer tests were suggested for detecting ASAs without any subjective judgment, and results were the same as in standard tests. This modification of ASAs analysis has a great future perspective [153].

Because of great variety of the methods used in ASAs studies, there is considerable discrepancy in results. It makes difficult comparative studies and the prevalence of ASAs in the populations still is not understood accurately [15, 24, 41, 154-158].

\section{Conclusion}

There are several reasons for heterogeneity of the data obtained on ASAs by various laboratories. First, the sample sizes are noteworthy. In most studies, they rarely exceed 100 of cases. Only in a few cohorts more than 1000 men from infertile couples were examined, but there was no comparison group adequate in terms of the number of patients (with varicocele or with autoimmune diseases). Secondly, the groups are heterogeneous in terms of age, race, degree of varicocele, duration of surgical correction, anamnestic data and comorbidity. Thirdly, a number of authors determined ASAs only in the blood serum or only in the ejaculate, only few determined ASAs in both biological fluids. Researchers have identified different Ig isotypes, either in isolation or in various combinations.

Until now, there is no standardized and globally accepted test for the determination of ASAs, and the question remains unresolved which method is optimal for screening and for final characterization of ASAs. A large number of sperm autoantigens have been described. The ASAs may have agglutinating, immobilizing, cytotoxic activities - depending on their precise specificity. Autoimmune infertility, most likely, occurs due to the combined effect of various autoantibodies to many sperm antigens. It is definitely one of the reasons for the controversy over the relationship between ASAs and immunological infertility in men.

It has not been agreed which cut levels should be thresholds for clinical value of various ASAs, neither in serum, nor in ejaculate, which leads to a lack of consensus on the clinical significance of positive ASAs tests.

The male infertility remains at the moment one of the leading reasons for the decline of demographic indicators worldwide. The presence of ASAs in high titers is associated with infertility in men. But nowadays there is no standardized method for detecting ASAs in various parts of the reproductive system.

Author Contributions: Conceptualization, V.C. and L.C.; writing-original draft preparation, S.P., Y.B., M.C. and A.I.; writing - review and editing, L.C. and Y.S..; supervision, V.C. and L.C.; project administration, V.C. and L.C; funding acquisition, V.C. and L.C. All authors have read and agreed to the published version of the manuscript. 
Funding: This research was carried out within the framework of the state assignment of the Institute of Philosophy of the Ural Branch of the Russian Academy of Sciences (topic No. AAAA-A18-118020590108-7).

This research was supported by a Grant from the Government of the Russian Federation for support of the studies conducted under the supervision of leading scientists (Contract no. 14. W03. 31. 0009 of 13.02. 2017).

Institutional Review Board Statement: Ethical review and approval were waived for this study, because it is review of literature.

Informed Consent Statement: N/A., because no patients were involved

Acknowledgments: Authors are grateful to Prof. Andrew I. Gorelov M.D., Ph.D., for valuable consultations as regards to the clinical aspects of the article concept.

Conflicts of Interest: The authors declare no conflict of interest. The funders had no role in the design of the study; in the collection, analyses, or interpretation of data; in the writing of the manuscript, or in the decision to publish the results.

\section{References}

1. Xu Y.C., Jing L.I., Liang W.B., Zhu W.J. Evaluation on antisperm antibody in infertile men with oligoasthenoteratozoospermia. J. Reprod. Contracept. 2014, 25, 49-53, doi: 10.7669/j.issn.1001-7844.2014.01.0049.

2. Shevyrin A.A. Modern view on treatment of male infertility. Russian Medical Review, 2018, 12, 30-35. (in Russian).

3. Kalinichenko S.Yu., Tyuzikov I.A. Oxidative stress and male infertility are interrelated pandemics of the 21st century. Modern pharmacotherapeutic possibilities of pathogenetic correction of spermatogenesis disorders with L-carnitine/acetyl-L-carnitine preparations. Urology and Nephrology. Special issue "Men's health", 2017, 22, 6-19. (in Russian).

4. Baskaran S., Agarwal A., Selvam M.K.P., Finelli R., Robert K.A. et al. Tracking Research Trends and Hotspots in Sperm DNA Fragmentation Testing for the Evaluation of Male Infertility: A Scientometric Analysis. Reprod Biol Endocrinol. 2019, 17(1), 110, doi: 10.1186/s12958-019-0550-3

5. Vybornov S.V., Asfandiyarov F.R., Seidov K.S., Kruglov V.A. Antioxidants in the treatment of patients with inflammatory diseases of the male reproductive system, complicated by excretory toxic form of infertility. Experimental and Clinical Urology, 2018, 3, 74-78. (in Russian)

6. Kirilenko E.A., Onopko V.F. Oxidative stress and male fertility: a modern view on the problem. Acta Biomedica Scientifica, 2017, 2(2), 102-108, doi: 10.12737/article_59a614fd84d146.40261567 (In Russian)

7. Vickram A.S., Dhama K. , Chakraborty S., Samad H.A. et al. Role of Antisperm Antibodies in Infertility, Pregnancy, and Potential for Contraceptive and Antifertility Vaccine Designs: Research Progress and Pioneering Vision. Vaccines (Basel)., 2019, 17(3), 116, doi: 10.3390/vaccines7030116

8. Shirshov V.N. Current state of the male infertility problem: the review of European Association of Urology clinical guidelines. Journal of Clinical Practice, 2016, 7(1), 39-50, doi: 10.17816/clinpract7139-50 (in Russian)

9. Epanchintseva E.A., Selyatitskaya V.G., Mitrofanov I.M., Pinkhasov B.B., Sviridova M.A. Antisperm antibodies under infertility in males, connection with abdominal obesity. Advances in current natural sciences, 2015, 4, 24-27. (in Russian)

10. Dorofeev S.D., Efremov E.A., Simakov V.V. Management of idiopathic pathospermia. Effective pharmacotherapy. Urologiya $i$ Nefrologiya, 2015, 2, 24-30. (in Russian)

11. Xu F., Ye L., Hu Y., et al. A novel protein biochip screening serum anti-sperm antibody expression and natural pregnancy rate in a follow-up study in Chinese infertility. Biosci Rep., 2020, 40(2), BSR20191769, doi:10.1042/BSR20191769

12. Potekhina E.S., Mikhailyuk E.V., Nepomnyashchikh A.S. Spermogram as an instrument for assessing male fertility. Science Review, 2020, 1, 11-14. doi: 10.17513/srms.1093 (in Russian)

13. Khairutdinov K.N., Sitdykova M.E., Zubkov A.Yu. Male infertility is the problem of XXI century. Obstetrics and gynecology, 2018, 6, 185-189 (in Russian)

14. Silva C.A, Cocuzza M., Carvalho J.F., Bonfá E. Diagnosis and classification of autoimmune orchitis. Autoimmun Rev., 2014, 13(4-5), 431-434, doi:10.1016/j.autrev.2014.01.024

15. Wald M. Male infertility: Causes and cures. Sexuality, Reproduction E Menopause, 2005, 3(2), 83-87.

16. Schmidt A.A., Zamyatnin S.A., Gonchar I.S., Korovin A.E. Risk factors of the development of male infertility. Clinical Pathophysiology, 2019, 25(4), 56-60. (in Russian) . Access: https://www.elibrary.ru/item.asp?id=42461303

17. Avadieva N.E. The use of DNA semen fragmentation in andrological practice. Vestnik Urologii, 2019 ,7(1), 7-11, doi: 10.21886/2308-6424-2019-7-1-7-11 (in Russian)

18. Likhonosov N.P., Ayub A.Kh., Babenko A.Yu., Borovets S.Yu. The role of inhibin B in the regulation of spermatogenesis and its clinical significance in male infertility. Urologicheskie vedomosti, 2019, 9(1), 39-45, doi: 10.17816/uroved9139-45 (in Russian)

19. Apolikhin O.I., Moskaleva N.G., Komarova V.A. Contemporary demographic situation and problems of improving the reproductive health of Russian population. Experimental and Clinical Urology, 2015, 4, 4-14 (in Russian) 
20. Lutov Yu.V., Selyatitskaya V.G., Epanchintseva E.A., Ryabinchenko T.I. The relationship between the andrological status of adolescents with anthropometric and hormonal indicators. Human physiology, 2014, 40(4), 124-131, doi: 10.7868/ S0131164614040109 (in Russian)

21. Jiang Y., Cui D., Du Y., et al. Association of anti-sperm antibodies with chronic prostatitis: A systematic review and meta-analysis. J Reprod Immunol. 2016, 118, 85-91, doi:10.1016/j.jri.2016.09.004

22. Paoli D., Gilio B., Piroli E. et al. Testicular tumors as a possible cause of antisperm autoimmune response. Fertil Steril. 2009, 91(2) 414-419, doi:10.1016/j.fertnstert.2007.11.084

23. Joki-Korpela P., Sahrakorpi N., Halttunen M., Surcel H.M., Paavonen J., Tiitinen A. The role of Chlamydia trachomatis infection in male infertility. Fertil Steril. 2009, 91(4 Suppl), 1448-1450, doi:10.1016/j.fertnstert.2008.06.051

24. Hulusi B. Z., Hakan Y. Antisperm antibodies: fact or fiction? Immunol Allergy Clin N Am, 2002, 22, 471-501,. doi: 10.1016/S0889-8561(02)00010-3

25. Kurpisz M., Havryluk A., Nakonechnyj A., Chopyak V., Kamieniczna M. Cryptorchidism and long-term consequences. Reprod Biol., 2010, 10(1), 19-35, doi:10.1016/s1642-431x(12)60035-7

26. London E. On the doctrine of spermolysins. Proceeding 1 (with 1 phototypic table). Arkh. biol. Nauk (St. Petersburg). 1901, 9(1), 82-125. (In Russian)

27. London E. S. Contribution a l'étude des spermolysines. Archives des sciences biologiques, 1903, 9, 171.

28. Metalnikoff S. Etudes sur la spermotoxine. Ann. Inst. Pasteur, 1900, 14, 577-589.

29. Parida R. Human MOSPD2: A bacterial Lmb mimicked auto-antigen is involved in immune infertility. J Transl Autoimmun., 2019, 2(8), 1:100002, doi: 10.1016/j.jtauto.2019.100002

30. Restrepo W. Cardona Maya B. Anticuerpos antiespermatozoides y su asociación con la fertilidad. Actas Urol Esp., 2013, 37(9), 571-578.

31. Wasilewski T., Łukaszewicz-Zając M., J. Wasilewska J., B. Mroczko B. Biochemistry of infertility. Clinica Chimica Acta, 2020, 508, 185-190, doi: 10.1016/j.cca.2020.05.039

32. Kutteh W.H. Autoimmune factors and their influence on assisted reproduction. Immunol Allergy Clin N Am, 2002, $22,643-661$.

33. Wilson L. Sperm agglutinins in human semen and blood. Proc Soc Exp Biol Med. (N.Y.), 1954, 85(4), 652-625, doi: 10.3181/00379727-85-20982.

34. Rümke P. The presence of sperm antibodies in the serum of two patients with oligozoospermia. Vox Sang. (Basel), 1954, 4, 135-140.

35. Wakimoto Y., Fukui A., Kojima T., Hasegawa A., Shigeta M., Shibahara H. Application of computer-aided sperm analysis (CASA) for detecting sperm-immobilizing antibody. Am J Reprod Immunol., 2018, 79(3), doi: 10.1111/aji.12814.

36. Rümke P. Autospermagglutinins: a cause of infertility in men. Ann $N Y$ Acad Sci., 1965, 124(2), 696-701. doi: 10.1111/j.1749-6632.1965.tb18995.x.

37. Emin A., Konova E., Lichev D., Aivvazova N., Popov I., Radev R. The importance of the presence of antisperm antibodies in serum and ejaculate of men with infertility. Akush Ginekol (Sofiia), 2008, 47(2), 26-30

38. Chamley L.W., Clarke G.N. Antisperm antibodies and conception. Semin Immunopathol., 2007, 29(2), 169-184, doi: 10.1007/s00281-007-0075-2.

39. Restrepo B., Cardona-Maya W. Antisperm antibodies and fertility association. Actas Urol Esp., 2013, 37(9), 571-578, doi: 10.1016/j.acuro.2012.11.003.

40. Cui D., Han G., Shang Y., Liu C., Xia L., Li L., Yi S. Antisperm antibodies in infertile men and their effect on semen parameters: a systematic review and meta-analysis. Clin Chim Acta, 2015, 15( 444), 29-36, doi: 10.1016/j.cca.2015.01.033.

41. LuS. M., Li X., Wang S. L., Yang X. L. et al. Success rates of in vitro fertilization versus intracytoplasmic sperm injection in men with serum anti-sperm antibodies: a consecutive cohort study. Asian J Androl., 2019, 21(5), 473-477, doi: 10.4103/aja.aja_124_18

42. Yasin A.L., Basha W.S. The Epidemiology of Anti-Sperm Antibodies Among Couples with Unexplained Infertility in North West Bank, Palestine. J Clin Diagn Res., 2016, 10(3), QC01-3, doi: 10.7860/JCDR/2016/15788.7380.

43. Bieniek J. M. , Drabovich A. P., Lo K. C. Seminal biomarkers for the evaluation of male infertility. Asian J Androl., 2016, 18(3), 426-433, doi: 10.4103/1008-682X.175781.

44. Westerman R. Biomarkers for demographic research: sperm counts and other male infertility biomarkers. Biodemography Soc Biol., 2020, 65(1), 73-87, doi: 10.1080/19485565.2019.1706150.

45. Tyuzikov I.A., Kalinichenko S.Yu., Vorslov L.O., Tishova Yu.A. Male infertility and insulin resistance: are there pathogenetic links and who, when and how should diagnose and treat? Experimental and Clinical Urology, 2014, 2, 68-75. (in Russian)

46. McLachlan R.I. Basis, diagnosis and treatment of immunological infertility in men. J Reprod Immunol., 2002, 57(1-2), 35-45, doi: 10.1016/s0165-0378(02)00014-1

47. Dörr H., Bohring C., Krause W. Are antisperm antibodies indeed sperm-specific? Andrologia., 2005, 37(5), 185-187, doi: 10.1111/j.1439-0272.2005.00675.x

48. Piroozmand A., Nasab S. D. M., Erami M., Hashemi S. M. A. et al. Distribution of Human Papillomavirus and Antisperm Antibody in Semen and Its Association with Semen Parameters Among Infertile Men. J Reprod Infertil., 2020, 21(3), 183-188.

49. Tchiokadze Sh., Galdava G. Clinical and anamnestic characteristics of development of antispermimmunity in infertile men. Georgian Med News, 2015, 246, 18-22. 
50. Patel A. S., Leong J. Y., Ranjith Ramasamy R. Prediction of male infertility by the World Health Organization laboratory manual for assessment of semen analysis: A systematic review. Arab J Urol., 2017, 16(1), 96-102, doi: 10.1016/j.aju.2017.10.005.

51. Adams C.E, Wald M. Risks and complications of vasectomy. Urol Clin North Am. 2009, 36(3), 331-336, doi:10.1016/j.ucl.2009.05.009

52. Amory J.K. Male contraception. Fertil Steril. 2016, 106(6), 1303-1309, doi:10.1016/j.fertnstert.2016.08.036

53. Matzinger P. The danger model: a renewed sense of self. Science. 2002, 296(5566), 301-305, doi: 10.1126/science.1071059.

54. Fijak M., Meinhardt A. The testis in immune privilege. Immunol Rev., 2006, 213, 66-81,. doi: 10.1111/j.1600-065X.2006.00438.x.

55. Majzoub A., Esteves S.C., Gosálvez J., Agarwal A. Specialized sperm function tests in varicocele and the future of andrology laboratory. Asian J Androl., 2016, 18(2), 205-212, doi: 10.4103/1008-682X.172642.

56. Jiang H., Zhu W.J. Testicular microlithiasis is not a risk factor for the production of antisperm antibody in infertile males. Andrologia, 2013, 45(5), 305-309, doi: 10.1111/and.12002.

57. Bozhedomov V.A, Teodorovich O.V. Epidemiology and causes of autoimmune male infertility. Urologiia, 2005, 1, 35-44.

58. Al-Adi A.M., El-Karamany T., Issa H., Zaazaa M. The influence of antisperm antibodies, intratesticular haemodynamics and the surgical approach to varicocelectomy on seminal variables. Arab J Urol., 2014, 4(12), 309-317, doi: 10.1016/j.aju.2014.07.001.

59. Archana S.S., Selvaraju S., Binsila B.K., Arangasamy A., Krawetz S. A. Immune regulatory molecules as modifiers of semen and fertility: A review. Mol Reprod Dev., 2019, 86(11), 1485-1504, doi: 10.1002/mrd.23263.

60. Fijak M., Pilatz A., Hedger M. P., Nicolas N. et al. Infectious, inflammatory and 'autoimmune' male factor infertility: how do rodent models inform clinical practice? - Hum Reprod Updat, e 2018, 24(4), 416-441, doi: 10.1093/humupd/dmy009.

61. Nagaria T, Sirmor N. Misoprostol vs. mifepristone and misoprostol in second trimester termination of pregnancy. J Obstet Gynaecol., 2011, 659.

62. Ombelet W., Bosmans E., Cox A., Janssen M., Mestdagh G. et al. In search for the general population's semen profile: the study of sperm parameters in partners of women with chronic anovulation. Facts Views Vis Obgyn., 2009, 18-26.

63. Leushuis E., van der Steeg J.W., Steures P., Repping S., Schols W. et al. Immunoglobulin G antisperm antibodies and prediction of spontaneous pregnancy. Fertil Steril., 2009, 1659

64. Nishlag E., Bere G.M. Andrology. Male Reproductive Health and Dysfunction, edited by E. Nishlag and G.M. Bere. Medical news agency: Moscow, 2005, 551 p. (in Russian)

65. Cheng C.Y., Mruk D.D. The blood-testis barrier and its implications for male contraception. Pharmacol Rev., 2012, 64(1), 16-64, doi:10.1124/pr.110.002790

66. Gong J., Zeng Q., Yu D., Duan Y.G. T Lymphocytes and Testicular Immunity: A New Insight into Immune Regulation in Testes. Int J Mol Sci,. 2020, 22(1), 57, doi: 10.3390/ijms22010057.

67. Duan Y.G., Gong J., Yeung W.S.B., Haidl G., Allam J.P. Natural killer and NKT cells in the male reproductive tract. J. Reprod. Immunol., 2020, 142, 103178, doi: 10.1016/j.jri.2020.103178.

68. Dufour J.M., Lord S.J., Kin T., Rayat G.R., Dixon D.E., Bleackley R.C., Korbutt G.S., Rajotte R.V. Comparison of successful and unsuccessful islet/Sertoli cell cotransplant grafts in streptozotocin-induced diabetic mice. Cell Transplant., 2008, 16, 1029-1038, doi: 10.3727/000000007783472417.

69. Guazzone V.A., Jacobo P., Theas M.S., Lustig L. Cytokines and chemokines in testicular inflammation: A brief review. Microsc. Res. Tech., 2009, 72, 620-628, doi: 10.1002/jemt.20704.

70. Lotti F., Baldi E., Corona G., F Lombardo F., Maseroli E. et al. Epididymal more than testicular abnormalities are associated with the occurrence of antisperm antibodies as evaluated by the MAR test. Hum Reprod., 2018, 33(8), 1417-1429, doi: 10.1093/humrep/dey235.

71. Friend D.S, Gilula N.B. Variations in tight and gap junctions in mammalian tissues. J Cell Biol., 1972, 53(3), 758-776, doi: 10.1083/jcb.53.3.758.

72. Chereshnev V.A., Rybina I.V., Beikin Ya.B., Oboskalova T.A. Immunological and genetic factors of reproductive disorders. UB RAS Publisher: Ekaterinburg, 2005, 175 P. (in Russian)

73. Clark S., Naz R.K. Presence and incidence of IZUMO antibodies in sera of immunoinfertile women and men. Am J Reprod Immunol., 2013, 69(3), 256-263, doi: 10.1111/aji.12060.

74. Nowicka-Bauer K., Kamieniczna M., Cibulka J., Ulcova-Gallova Z., Kurpisz M. Proteomic identification of sperm antigens using serum samples from individuals with and without antisperm antibodies. Andrologia, 2016, 48(6), 693-701, doi: 10.1111/and.12502

75. Lu, J.-C., Huang, Y.-F., \& Lu, N.-Q. Antisperm immunity and infertility. Expert Review of Clinical Immunology, 2008, 4(1), 113-126. doi:10.1586/1744666x.4.1.113

76. Carlsson L, Ronquist G, Nilsson BO, Larsson A. Dominant prostasome immunogens for sperm-agglutinating autoantibodies of infertile men. J Androl. 2004, 25(5):699-705. doi: 10.1002/j.1939-4640.2004.tb02844.x.

77. Pavlásek J., Peknicová J., Ulcová-Gallová Z., Nováková P., Reischig J., Micanová Z., Rokyta Z. Significance of determination of intra-acrosomal proteins and sperm antibodies in human reproduction. Ceska Gynekol., 2004, 69(4), 306-311.

78. Bonyadi M.R., Madaen S.K., Saghafi M. Effects of Varicocelectomy on Anti-sperm Antibody in Patients with Varicocele. J Reprod Infertil., 2013, 2(14), 73-78.

79. Shibahara H., Tsunoda T., Taneichi A., Hirano Y., Ohno A., Takamizawa S., Yamaguchi C., Tsunoda H., Sato I. Diversity of antisperm antibodies bound to sperm surface in male immunological infertility. Am J Reprod Immunol., 2002, 47(3), 146-150, doi: 10.1034/j.1600-0897.2002.10059.x 
80. Lopes L. S., Cury V. N., Cha J. D., Junior V. M. L. et al. Do assisted reproduction outcomes differ according to aetiology of obstructive azoospermia? Andrologia, 2020, 52(1), e13425, doi: 10.1111/and.13425.

81. Bozhedomov V.A., Lipatova N.A., Alexeev R.A., Alexandrova L.M., Nikolaeva M.A., Sukhikh G.T. The role of the antisperm antibodies in male infertility assessment after microsurgical varicocelectomy. Andrology, 2014, 6(2), 847-855, doi: 10.1111/j.2047-2927.2014.00254.x.

82. Bozhedomov V.A., Lipatova N.A., Rokhlikov I.M., at al. Male fertility and varicocoele: role of immune factors. Andrology, 2014, 1(2), 51-58,. doi: 10.1111/j.2047-2927.2013.00160.x.

83. Al-Daghistani H.I., Hamad A.W., Abdel-Dayem M., Al-Swaifi M., Abu Zaid M. Evaluation of Serum Testosterone, Progesterone, Seminal Antisperm Antibody, and Fructose Levels among Jordanian Males with a History of Infertility. Biochem Res Int., 2010. doi: 10.1155/2010/409640.

84. Bohring C., Krause W. Differences in the antigen pattern recognized by antisperm antibodies in patients with infertility and vasectomy. J Urol., 2001, 166(3), 1178-1180.

85. Zhao Y., Zhao E., Zhang C, Zhang H. Study of the Changes of Acrosomal Enzyme, Nitric Oxide Synthase, and Superoxide Dismutase of Infertile Patients with Positive Antisperm Antibody in Seminal Plasma. Cell Biochem Biophys., 2015, 3(73), 639-642, doi: 10.1007/s12013-015-0641-5.

86. Gatimel N., Moreau J., Isus F., Moinard N. at al. Anti-sperm antibodies detection by a modified MAR test: Towards a better definition of its indications. Reprod Biomed Online, 2018, 37( 6), 717-723, doi: 10.1016/j.rbmo.2018.09.011.

87. Dabrowski F.A, Grzechocinska B., Wielgos M. The role of vitamin D in reproductive health--a Trojan Horse or the Golden Fleece? Nutrients, 2015, 7(6), 4139-4153 doi:10.3390/nu7064139

88. Silva, A. F., Ramalho-Santos, J., \& Amaral, S. The impact of antisperm antibodies on human male reproductive function: an update. Reproduction, 2021, 162(4), R55-R71, doi: 10.1530/REP-21-0123.

89. Clarke G.N. Association between sperm autoantibodies and enhanced embryo implantation rates during in vitro fertilization. Fertil Steril., 2006, 753.

90. Esteves S.C., Schneider D.T., Verza S. Jr. Influence of antisperm antibodies in the semen on intracytoplasmic sperm injection outcome. Int Braz J Urol., 2007, 33(6), 795-802, doi:10.1590/s1677-55382007000600007

91. Lombardo F., Gandini L., Lenzi A., Dondero F. Antisperm immunity in assisted reproduction. J Reprod Immunol., 2004, 62(1-2), 101-109. doi:10.1016/j.jri.2003.08.005

92. Clarke G.N. Etiology of sperm immunity in women. Fertil Steril., 2009, 91(2), 639-643, doi:10.1016/j.fertnstert.2007.11.045

93. Bahraminejad R., Kadanali S., Erten O., Bahar H. Reproductive failure and antisperm-antibody production among prostitutes. Acta Obstet. Gynecol. Scand., 1999, 70 (6), 483-485.

94. Yang Y.X., Zhu W.J., Ren X. Evaluation of Circulating ASAs in Women with Secondary Infertility. J. Reprod. Contracept., 2011, 22(4), 195-200, doi: 10.1016/S1001-7844(12)60015-7

95. Witkin, S. S., \& David, S. S. (1988). Effect of sperm antibodies on pregnancy outcome in a subfertile population. American Journal of Obstetrics and Gynecology, 1988, 158(1), 59-62, doi:10.1016/0002-9378(88)90776-4.

96. Naz, R. K. Effects of Antisperm Antibodies on Early Cleavage of Fertilized Ova1. Biology of Reproduction, 1992, 46(1), 130-139. doi:10.1095/biolreprod46.1.130

97. Yang Y.X., Zhu W.J., Li J. Evaluation of Circulating Antisperm Antibody in Infertile Women with Polycystic Ovary Syndrome. J. Reprod. Contracept, 2012, 23(1), 25-28, doi: 10.1016/S1001-7844(13)60003-6

98. Zhu W., Jiang H. Circulating Antisperm Antibody is not Related to the Pathogenesis of Infertility in Women with Endometriosis. J. Reprod. Contracept, 2012, 23(2),75-80, doi:10.1016/S1001-7844(13)60009-7

99. Wang Y.X., Zhu W.J. Circulating antisperm antibody (ASAs) in women is not associated with missed abortions at the first-trimester pregnancy. J. Reprod. Contracept., 2011, 22, 139-143, doi: 10.1016/S1001-7844(12)60009-1.

100. Vad S., Szanto A., Tarr T., Vegh J., Naggy G., Zeher M. Immunological disorders in reproductive failure. J Reprod Immunol., 2014, 101-102, 40-60

101. Neimark A.I., Neimark B.A., Davydov A.V. and others. Rehabilitation of patients with male infertility after varicocelectomy. Effective pharmacotherapy, 2018, 9, 8-12. (in Russian)

102. Evdokimov V.V., Zakharikov S.V., Kastrikin Yu.V. Varicocele in children and adolescents. Treatment and prevention. 2017, 21(1), 53-56. (in Russian)

103. Will M.A., Swain J., Fode M., Sonksen J., Christman G.M., Ohl D. The great debate: varicocele treatment and impact on fertility. Fertil Steril., 2011, 95(3), 841-852, doi:10.1016/j.fertnstert.2011.01.002

104. Komarova S.Yu., Tsap N.A. Ways to reduce the risk of reproductive loss in children with varicocele. Medical science and education of the Urals, 2017, 1, 98-101. (in Russian)

105. Neimark A.I., Popov I.S., Gazamatov A.V. Features of the microcirculation of the prostate and gonads in young men suffering from isolated varicocele and varicocele in combination with pelvic congestion. Andrology, 2013, 2, 56-60. (in Russian)

106. Efremov E.A., Shekhovtsov S.Yu., Butov A.O., Kastrikin Yu.V., Kozdoba A.S., Garaev T.I. The effect of varicocele on hormones and the reproductive system in men. Experimental and Clinical Urology, 2019, 1, 102-106. (in Russian)

107. Ramalingam M., Kini S., Mahmood T. Male fertility and infertility. Obstetrics, Gynaecology and Reproductive Medicine, 2014, 24(11), 326-332.

108. Will M. A., Swain J., Fode M., Jens Sonksen J., Christman G. M., Ohl D. The great debate: varicocele treatment and impact onfertility. Fertil Steril., 2011, 95(3), 841-852, doi:10.1016/j.fertnstert.2011.01. 
109. Komarova S.Yu. Problems and prospects of andrological care for children in predicting the reproductive status of a megacity. Ural Medical Journal. Pediatric urology, 2013, 9, 10-13. (in Russian)

110. Madar J., Urbánek V., Chaloupková A., Nouza K., Kinský R. Role of sperm antibodies and cellular autoimmunity to sperm in the pathogenesis of male infertility. Ceska Gynekol., 2002, 67(1), 3-7.

111. Hassanin A. M., Ahmed H. H., Kaddah A. N. A Global View of the Pathophysiology of Varicocele. Andrology, 2018, 6(5), 654-661, doi: 10.1111/andr.12511.

112. Heidenreich A., Bonfig R., Wilbert D.M., Strohmaier W.L., Engelmann U.H. Risk factors for antisperm antibodies in infertile men. Am J Reprod Immunol., 1994, 31(2-3), 69-76, doi: 10.1111/j.1600-0897.1994.tb00849.x

113. Gilbert B.R., Witkin S.S., Goldstein M. Correlation of sperm-bound immunoglobulins with impaired semen analysis in infertile men with varicoceles. Fertil Steril., 1989, 52(3), 469-473.

114. Knudson G., Ross L., Stuhldreher D., Houlihan D., Bruns E., Prins G. Prevalence of sperm bound antibodies in infertile men with varicocele: the effect of varicocele ligation on antibody levels and semen response. J Urol., 1994, 151, 1260-1262, doi: 10.1016/s0022-5347(17)35226-6.

115. Ulcova-Gallova Z., Gruberova J., Vrzalova J., Bibkova K., Peknicova .J, Micanova Z., Topolcan O. Sperm antibodies, intra-acrosomal sperm proteins, and cytokines in semen in men from infertile couples. Am J Reprod Immunol., 2009, 61(3), 236-245, doi: 10.1111/j.1600-0897.2009.00686.x.

116. Ferrer M.S., Miller L.M.J. Equine sperm-bound antisperm antibodies are associated with poor semen quality. Theriogenology, 2018, 15(118), 212-218, doi: 10.1016/j.theriogenology.2018.05.034.

117. Kanevskaya T.A., Yatsyk S.P., Bezlepkina O.B. Hormonal status and markers of autoimmune disorders of spermatogenesis in adolescents who underwent surgical treatment for varicocele. Pediatric Pharmacology, 2010, 7(4), 92-94. (in Russian)

118. Oshinsky G.S., Rodriguez M.V., Mellinger B.C. Varicocele-related infertility is not associated with increased sperm-bound antibody. J Urol., 1993, 150(3), 871-873, doi: 10.1016/s0022-5347(17)35636-7

119. Veräjänkorva E, Laato M, Pöllänen P. Analysis of 508 infertile male patients in south-western Finland in 1980-2000: hormonal status and factors predisposing to immunological infertility. Eur J Obstet Gynecol Reprod Biol. 2003, 111(2):173-178. doi: 10.1016/s0301-2115(03)00312-9.

120. Yatsyk S.P., Kanevskaya T.A., Abramov K.S. Sharkov S.M., Fomin D.K. Reproductive health of children and adolescents who have undergone surgical correction in connection with andrological pathology. Pediatric Pharmacology, 2009, 6(1), 15-22. (in Russian)

121. Jensen C.F.S., Khan O., Nagras Z.G. Sønksen J., Fode M., Østergren P.B., Shah T, Ohl D.A., CopMich Collaborative. Male infertility problems of patients with strict sperm morphology between 5-14\% may be missed with the current WHO guidelines. Scand J Urol., 2018, 5-6(52), 427-431, doi: 10.1080/21681805.2018.1548503.

122. Berger G. K., Smith-Harrison L. I., Sandlow J. I. Sperm agglutination: Prevalence and contributory factors. Andrologia, 2019, 51(5), e13254, doi: 10.1111/and.13254.

123. Djaladat H., Mehrsai A., Rezazade M., Djaladat Y., Pourmand G. Varicocele and antisperm antibody: fact or fiction? South Med J., 2006, 99(1), 44-47.

124. Wigby S., Suarez S. S., Lazzaro B. P., Pizzari T., Wolfner M. F. Sperm success and immunity. Curr Top Dev Biol., 2019, 135, 287-313. doi: 10.1016/bs.ctdb.2019.04.002

125. Eggert-Kruse W., Weltin M., Strowitzki T. Are chlamydial lipopolysaccharide-directed antibodies in seminal plasma or serum clinically significant during investigation of male infertility?. Urology, 2011, 77(5), 1101-1106, doi:10.1016/j.urology.2010.11.014

126. Garolla A., Pizzol D., Bertoldo A., De Toni L., Barzon L., Foresta C. Association, prevalence, andclearance of human papillomavirusand antisperm antibodies in infected semen samples from infertile patients. Fertil Steril., 2013, 99, 125-131, doi: 10.1016/j.fertnstert.2012.09.006.

127. Thaper D., Prabha V. Molecular mimicry: An explanation for autoimmune diseases and infertility. Scand J Immunol., 2018, e12697, doi: 10.1111/sji.12697.

128. Merezhkovsky K.S. The theory of two plasmas as a basis symbiogenesis, a new doctrine of the origin of organisms. Kazan: Imperial Univ. Publishing House, 1909, 102 p.

129. Kanduc D. The role of proteomics in defining autoimmunity. Expert Rev Proteomics, 2021, 18(3), 177-184, doi: 10.1080/14789450.2021.1914595.

130. Pashnina I.A., Krivolapova I.M., Fedotkina T.V., Ryabkova V.A., Chereshneva M.V., Churilov L.P., Chereshnev V.A. Antinuclear Autoantibodies in Health: Autoimmunity Is Not a Synonym of Autoimmune Disease. Antibodies (Basel)., 2021, 10(1), 9, doi: 10.3390/antib10010009.

131. Ahuja A. K., Cheema R. S. Homology between cattle bull sperm and bacterial antigenic proteins viz a viz possible role in immunological infertility. Reprod Domest Anim., 2018, 53(6), 1530-1538. doi: 10.1111/rda.13292

132. Zupin, L., Pascolo, L., Zito, G., Ricci, G., \& Crovella, S. SARS-CoV-2 and the next generations: which impact on reproductive tissues? Journal of Assisted Reproduction and Genetics, 2020, 37(10), 2399-2403, doi:10.1007/s10815-020-01917-0

133. Haghpanah A., Masjedi F., Alborzi S., Hosseinpour A., Dehghani A., Malekmakan L., Roozbeh J. Potential mechanisms of SARS-CoV-2 action on male gonadal function and fertility: Current status and future prospects. Andrologia, 2021, 53(1), e13883, doi: 10.1111/and.13883.

134. Xu, J., Qi, L., Chi, X., Yang, J., Wei, X., Gong, E., Peh, S. \& Gu, J. Orchitis: A complication of severe acute respiratory syndrome (SARS). Biology of Reproduction, 2006, 74(2), 410-416, doi:10.1095/biolreprod.105.044776. 
135. Gagliardi L., Bertacca C., Centenari C., Merusi I., Parolo E., Ragazzo V., Tarabella, V. Orchiepididymitis in a boy with COVID-19. The Pediatric Infectious Disease Journal, 2020, 39(8), e200-e202,doi: 10.1097/INF.0000000000002769

136. Shetty J., Klotz K.L., Wolkowicz M.J., Flickinger C.J., Herr J.C. Radial spoke protein 44 (human meichroacidin) is an axonemal alloantigen of sperm and cilia. Gene, 2007, 396(1), 93-107, doi: 10.1016/j.gene.2007.02.031.

137. Krassas G.E., Markou K.B. The impact of thyroid diseases starting from birth on reproductive function. Hormones (Athens), 2019, 18(4), 365-381, doi:10.1007/s42000-019-00156-y

138. La Vignera S., Vita R., Condorelli R.A. et al. Impact of thyroid disease on testicular function. Endocrine, 2017, 58(3), 397-407. doi:10.1007/s12020-017-1303-8

139. Churilov L.P., Stroev Y.I., Serdyuk I.Y., Kaminova-Mudzhikova O.M., Belyaeva I.V., Gvozdetsky A.N., Nitsa N.A., Mikhailova L.R. Autoimmune thyroiditis: Centennial jubilee of a social disease and its comorbidity. Pathophysiology, 2014, 21(2), 135-145, doi: 10.1016/j.pathophys.2013.11.002.

140. Linquette M., Fossati P. Hyperprolactinismes et anti-prolactiniques. Sem Hop., 1977, 53(24),1431-8, PMID: 197633.

141. Borba V.V., Zandman-Goddard G., Shoenfeld Y. Prolactin and autoimmunity: The hormone as an inflammatory cytokine. Best Pract Res Clin Endocrinol Metab., 2019, 33(6), 101324, doi: 10.1016/j.beem.2019.101324.

142. Krassas G.E., Poppe K., Glinoer D. Thyroid function and human reproductive health. Endocr Rev., 2010, 31(5), 702-755, doi:10.1210/er.2009-0041

143. Gubbi S., Hannah-Shmouni F., Verbalis J.G., Koch C.A. Hypophysitis: An update on the novel forms, diagnosis and management of disorders of pituitary inflammation. Best Pract Res Clin Endocrinol Metab., 2019, 33(6), 101371, doi:10.1016/j.beem.2019.101371

144. Iukhta A.I., Stroev Yu.I., Churilov L.P. Reproductiveness in men with Hashimoto's thyroiditis. Health - the Basis of Human Potential. Problems and Ways to Solve Them. 2020, 15(1), 314-322. (in Russian). Access: https://www.elibrary.ru/download/elibrary_44481865_34712045.pdf

145. Iukhta A.I . On the pathogenesis of male infertility in Hashimoto's thyroiditis. Actual Problems of Biomedicine - 2021: Proceedings of the XXVII All-Russia's Conference of Young Scientists with International Participation, St. Petersburg, March 25-26, 2021: Saint Petersburg: I.P. Pavlov First SPbSMU Publisher, 2021, 134-136. (in Russian). Access: http://www.pathophysiology.ru/АРВ2021/Сборник\%20АПБ-2021.pdf

146. Churilov L. P., Stroev Yu. I., Mudzhikova O. M. Ageing, thyroid and autoallergy: new insight into pathogenesis and treatment. $\begin{array}{lllll}\text { Wiener Klinische Wochenschrift, } & \text { 2009, } & \text { 121(7-8), } & 70-71 .\end{array}$ https://link.springer.com/content/pdf/10.1007/s00508-009-1195-6.pdf

147. Mihara S., Suzuki N., Wakisaka S., Suzuki S., Sekita N., Yamamoto S., Saito N., Hoshino T., Sakane T. Effects of thyroid hormones on apoptotic cell death of human lymphocytes. J Clin Endocrinol Metab., 1999, 84(4), 1378-1385, doi: 10.1210/jcem.84.4.5598.

148. Dasu N., Khalid Y., Panuganti S., Daly S. Amiodarone induced epididymo-orchitis. Urol Case Rep., 2019, 26, 100929, doi: 10.1016/j.eucr.2019.100929.

149. Safarian G. Kh., Niauri D. A., Borodina Ye. S., Dzhemlikhanova L. Kh., Gzgzyan A. M. Gender characteristics of autoimmune hypogonadism. Vestnik of Saint Petersburg University. Medicine, 2020, 15(1), 9-23, doi:10.21638/spbu11.2020.102.

150. Fichorova R., Nakov L., Baleva M., Nikolov K., Gegova I. Sperm, nuclear, phospholipid, and red blood cell antibodies and isotype RF in infertile couples and patients with autoimmune rheumatic diseases. Am J Reprod Immunol., 1996, 36(6), 309-316, doi: 10.1111/j.1600-0897.1996.tb00181.x.

151. Silva C.A., Cocuzza M., Borba E.F., Bonfá E. Cutting-edge issues in autoimmune orchitis. Clin Rev Allergy Immunol. 2012, 42(2), 256-263. doi: 10.1007/s12016-011-8281-z.

152. Shiraishi Y., Shibahara H., Koriyama J. et al. Incidence of antisperm antibodies in males with systemic autoimmune diseases. Am J Reprod Immunol., 2009, 61(3), 183-189, doi:10.1111/j.1600-0897.2008.00676.x

153. Sikka, S.C., Hellstrom, W.J.G. Tests for antisperm antibodies. Infertility in the Male, 2019 , 603-612. doi:10.1017/cbo9780511635656.038

154. Ferguson A.C. Detection of antisperm antibodies in equine semen using the immunobead test. Animal Reproduction Science, 2010,121S, 151-152. doi: 10.1016/j.anireprosci.2010.04.031

155. WHO laboratory manual for the examination and processing of human semen. 6th ed. Geneva, Switzerland: WHO Press, 2021. 292 p.

156. Shibahara H., Wakimoto Y., Fukui A., Hasegawa A. Anti-sperm antibodies and reproductive failures. Am J Reprod Immunol., 2021, 85(4), e13337, doi:10.1111/aji.13337

157. Barbonetti A., Castellini C., D'Andrea S., G Cordeschi G., Santucci R. Prevalence of anti-sperm antibodies and relationship of degree of sperm auto-immunization to semen parameters and post-coital test outcome: a retrospective analysis of over 10000 men. Hum Reprod., 2019, 34(5), 834-841, doi: 10.1093/humrep/dez030

158. Barbonetti A., Castellini C., D'Andrea S., Minaldi E., Totaro M. Relationship between natural and intrauterine insemination-assisted live births and the degree of sperm autoimmunization. Hum Reprod., 2020, 35(6), 1288-1295, doi: 10.1093/humrep/deaa070. 